Article

\title{
Mapping Environmental Conflicts Using Spatial Text Mining
}

\author{
Jae-hyuck Lee(1) and Do-kyun Kim * \\ Korea Environment Institute, Sejong 30147, Korea; jaehyuck@kei.re.kr \\ * Correspondence: dkkim@kei.re.kr; Tel.: +82-44-415-7438
}

Received: 3 July 2020; Accepted: 20 August 2020; Published: 21 August 2020

check for updates

\begin{abstract}
Mapping the characteristics and extent of environmental conflicts related to land use is important for developing regionally specific policies. However, because it is only possible to verify the frequency of conflicts on a specific predetermined subject, it is difficult to determine the various reasons for conflicts in a region. Therefore, this study mapped the current status of regional environmental conflicts in South Korea using a spatial text mining technique, then proposed relevant management policies. The results were obtained by analyzing environmental conflict data extracted from the online agendas of regional environmental organizations. Air quality-related conflicts in South Korea are concentrated in western municipalities; development-related conflicts are concentrated in the southern region of Jeju Island; and intensive safety-related conflicts occur in metropolitan areas, particularly Ulsan. Thus, the type of conflict is determined by the local environment, in accordance with the definition of environmental conflict, and the distribution is determined by the location of the stakeholder population. This study reveals the issues and locations related to local environmental conflict that require further attention, and proposes more wide-ranging methods for managing the links between conflicts by mapping environmental conflicts on a large scale rather than on an individual basis.
\end{abstract}

Keywords: South Korea; environmental conflicts; spatial text mining; atmosphere; development; safety

\section{Introduction}

An environmental conflict is a social issue that originates from a difference in views among various stakeholders of environmental resources [1]. Environmental conflict is difficult to resolve, and different demands for limited resources may lead to war between countries and regions [2]. Therefore, many studies have attempted to find an effective solution to environmental conflict, with most research conducted in the form of individual case studies of conflict characteristics and solutions using either qualitative analysis methods, such as interviews and observations, or quantitative analysis methods, such as questionnaires and data from social networking services such as YouTube [3]. However, organizing and summarizing the results can be problematic. For example, content analysis was previously used to systematically organize case studies [1]; however, this attempt was limited as it only examined environmental conflicts that fit a classification framework determined by the researcher.

A potential alternative is to map then organize environmental conflicts. An environmental conflict, by definition, is closely related to land use [4]. The optimal method of land-use analysis involves mapping. As maps enable researchers to explore distinct characteristics and hotspots in a particular space, they represent an alternative to spatial planning-based organization. Carranza et al. [5] used this method to identify areas of fierce environmental conflicts in Chile by organizing and mapping conflicts reported in various newspapers. Their method represented an alternative to solving environmental conflicts by assessing their impact; however, it was not possible to identify the type of problems that intensified and their specific locations. Other studies have mapped major types of 
environmental conflict. Soytong and Perera [6] mapped environmental conflicts related to air and water quality using the degree of change in the main conflict factors; Kim and Arnhold [7] used the same method for environmental conflicts related to land erosion. Abram et al. [8] attempted to express environmental conflicts by modeling detailed data such as land use, land destruction, carbon content, hydrology, topography, accessibility, and infrastructure. However, these types of analyses can only map macroscopic environmental conflicts for which the required data exist; thus, their ability to capture the differing opinions of local residents is limited. Some studies have analyzed land-use preferences on a micro scale using the public participation GIS method, which reflects the opinion of stakeholders in the field [9]; however, this method does not enable the scope of participation to be widely expanded.

Therefore, this study employs a spatial text mining technique to map and organize the content generated by stakeholders in various environmental conflict case studies. Text mining has been highlighted as a methodology that can replace existing interview and questionnaire techniques, as it can identify the main content of a given text [10]. Furthermore, this developing technique analyzes the characteristics and location of the main content. Häberle et al. [11] confirmed that the spatial distribution of Twitter content can be studied through various machine-learning techniques, and Gulnerman and Karaman [12] presented various techniques for mapping social-media data. Recent advances in these techniques have expanded their applications from comparing the location of McDonald's outlets to obesity incidence by spatializing Twitter data [13], to proposing methods for maximizing joy via an emotional analysis of space in a Disney park [14]. The present study maps environmental conflicts in South Korea, which has experienced various environmental conflicts due to rapid development in recent years, using spatial text mining and, where possible, online environmental conflict data provided by local governments. The study aims to use maps as an alternative analysis method of identifying the spatial context of environmental conflicts.

\section{Materials and Methods}

\subsection{Materials}

To analyze environmental conflicts in South Korea, data from the past two years (2017-2018) related to the environmental conflict-focused agendas of 39 active central and regional organizations, including the Korean Federation for Environmental Movement, Green Korea United, and Environmental Justice, were collected and analyzed. The collection was limited to two years of survey data, because the required information was only available for all environmental groups on the Internet for these years. Many environmental organizations had no data prior to 2016, and some failed to update their data in 2019.

These organizations are independent of the government and market, and have been representing critical and alternative voices related to regional environmental conflicts for a long time. Thus, the environmental conflicts studied by these environmental non-governmental organizations (NGOs) clearly reflect the needs of citizens; in other words, they are a major source of data on how environmental conflicts are experienced by the local population. This study collected 330 case studies documented by these organizations, including 155 in 2017 and 175 in 2018.

\subsection{Methods}

This study used spatial text mining to map environmental conflicts. The technique was designed to verify the content related to the issue of interest via its place in the material generated by the NGOs via keyword factor analysis of each space in the material (Figure 1). The detailed analysis procedure is as follows. First, morphological analysis was performed on the text of the agendas of the different NGOs. Morphological analysis divides text based on parts of speech in order to extract the words used in various types of speech from the text. Second, the main keywords were selected from the text, which were limited to nouns with independent meanings obtained from the morphological analysis. Then, the words in the top $10 \%$ according to their frequency were selected as the top keywords [15]. Third, 
a factor analysis was conducted on the main keywords in each space. After identifying the number of major keywords discussed by region, these values were used to conduct the factor analysis. As the characteristics of each major factor can be verified and the analysis process results in standardization, factor analysis was used as it does not increase the frequency of a keyword simply if there are a large number of discussions related to that keyword [16]. Fourth, the results of the regional factor analysis were mapped using ArcGIS. For each major factor (environmental conflict issue) with a high factor load value, the factor value of the local government was expressed using a color scale. Thus, the spatial distribution of the main environmental conflict issues was identified.

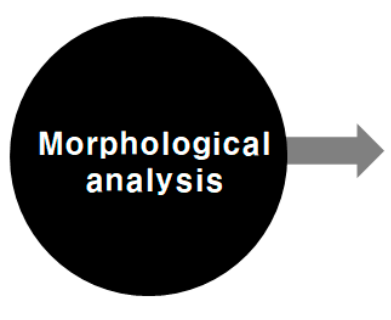

Morpheme analyzer

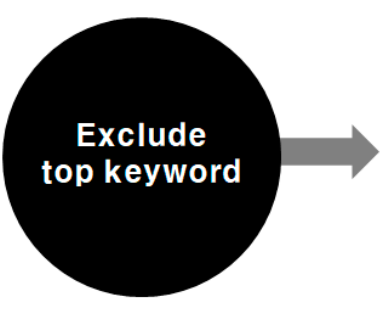

Excel

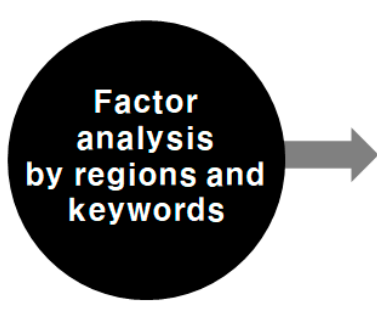

SPSS

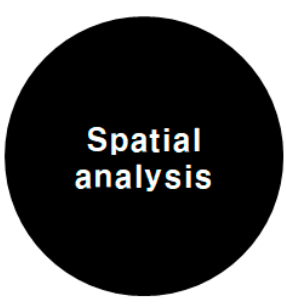

ArcGIS

Figure 1. Schematic of the research procedure.

\section{Results}

First, morphological analysis was performed on the content of all the environmental agendas of the various local governments, and then keywords were extracted. As a result, citizens and residents exhibited contrasting opinions on regional environmental problems through related words such as "project", "region", "environment", "citizen", and "resident" (Table 1). To confirm the regional differences in environmental conflicts, factor analysis was conducted for each region on selected keywords. Varimax rotation, which employs the most common Kaiser normalization technique, was used as the rotation method in factor extraction. As a result of the analysis, three factors with an eigenvalue of one or higher were extracted, with characteristics of "atmosphere", "development", and "safety" according to the related keywords. Distinct regional environmental problems were confirmed based on these three factors (Tables 2 and 3).

Factor 1 predominantly consisted of areas sensitive to the characteristic of "atmosphere." Seoul, Chungbuk, and Gyeonggi were very sensitive to problems related to the atmosphere, and the regions of Gwangju, Jeonnam, Chungnam, and Gangwon showed similar but lower sensitivity than the other three regions. Problems related to factor 1 were more widespread than those related to other factors, which confirms that the problem of fine dust in South Korea was the most serious environmental concern of citizens in the last two to three years. Issues related to the characteristic of "atmosphere" were major environmental concerns for communities in Seoul and Gyeonggi-do, because the inflow of fine dust from China is concentrated in areas with high populations and dense industrial facilities, and in Chungnam and Gangwon because of their high concentration of thermal power plants.

Factor 2 included areas that are sensitive to the characteristic of "development", such as Jeju, Gyeongbuk, and Jeonbuk. The intensity of this characteristic was lower in Gyeongnam and Incheon than in other regions but still high. In particular, the region of Jeju, which is the leading tourist destination in Korea, boasting beautiful natural scenery, has serious conflicts over environmental conservation and development for tourism; for example, construction of the Jeju 2 airport. Furthermore, the regions of Gyeongbuk and Jeonbuk, which are still relatively undeveloped, face strong pressure for development; therefore, the conflict between environmental conservation and development is the central axis of environmental problems in factor 2 areas.

Lastly, Factor 3 areas included those areas sensitive to the characteristic of "safety." Ulsan and Daegu were the most affected areas, followed by Busan and Daejeon. Ulsan, Busan, and Daejeon are adjacent or home to nuclear power plants and related research facilities. Large and small nuclear safety accidents continue to occur in these areas; thus, the stability of the "Hanaro" research reactor in 
Daejon, run by the Korea Atomic Energy Research Institute, is a key area of conflict in its community. Therefore, issues of nuclear safety are a major concern for local media and civil society as well as local environmental NGOs in these areas. In addition, asbestos damage and safety concerns have been a major environmental problem in Daegu over the past two years.

Table 1. Frequency (Freq) of major keywords selected for the analysis.

\begin{tabular}{|c|c|c|c|c|c|c|c|c|c|}
\hline Keyword & Freq & Keyword & Freq & Keyword & Freq & Keyword & Freq & Keyword & Freq \\
\hline Project & 253 & Construction & 68 & Jeju Island & 39 & Nuclear power plant & 33 & Restoration & 28 \\
\hline Region & 235 & Result & 66 & Conservation & 39 & Education & 33 & Law & 28 \\
\hline Environment & 175 & Organization & 64 & Composition & 39 & Waste & 32 & Public opinion & 28 \\
\hline Citizen & 175 & Ecology & 63 & Create & 38 & Destruction & 32 & Case & 28 \\
\hline Resident & 137 & Scale & 61 & Public-private & 38 & City of Incheon & 32 & Reinforcement & 28 \\
\hline Planning & 114 & Energy & 59 & Private & 38 & State & 32 & Permission & 27 \\
\hline Management & 113 & unit & 58 & Participation & 37 & Protection & 32 & Nuclear & 27 \\
\hline Park & 112 & Use & 55 & Nature & 37 & Public & 32 & Budget & 27 \\
\hline Problem & 109 & Development & 55 & Water quality & 37 & Decision & 32 & Plan & 27 \\
\hline Development & 108 & Installation & 53 & Opposition & 37 & Thermal & 31 & Open & 27 \\
\hline $\begin{array}{l}\text { Carry } \\
\text { forward }\end{array}$ & 100 & Prepare & 50 & Atmosphere & 37 & Applicable & 31 & $\begin{array}{l}\text { Korean Federation for } \\
\text { Environmental } \\
\text { Movement }\end{array}$ & 26 \\
\hline Progress & 94 & Demand & 49 & Improvement & 37 & Review & 31 & Solution & 26 \\
\hline Investigation & 94 & Emission & 49 & Confirmation & 36 & Mud flat & 31 & Demolition & 26 \\
\hline Need & 93 & Process & 48 & Administration & 36 & Open & 31 & Responsibility & 26 \\
\hline Pollution & 93 & Operation & 46 & Surrounding & 36 & Conflict & 31 & Measure & 26 \\
\hline Measure & 89 & Suspension & 45 & Accident & 36 & Bring up & 30 & Vicinity & 26 \\
\hline Government & 87 & Enforcement & 45 & Damage & 35 & After & 30 & Land & 26 \\
\hline Fine dust & 85 & Announcement & 45 & Continue & 35 & Schedule & 30 & Factory & 26 \\
\hline City & 82 & Situation & 43 & Implementation & 35 & Living & 30 & Detection & 26 \\
\hline Construction & 82 & School & 42 & Standard & 35 & Nakdong River & 30 & Sunlight & 25 \\
\hline $\begin{array}{c}\text { Power } \\
\text { plant }\end{array}$ & 79 & Activity & 41 & Possibility & 35 & $\begin{array}{l}\text { Shin-Kori nuclear } \\
\text { power plant }\end{array}$ & 30 & Local government & 25 \\
\hline Society & 77 & $\begin{array}{l}\text { Ministry of } \\
\text { Environment }\end{array}$ & 41 & Harm & 34 & Verification & 30 & System & 25 \\
\hline Policy & 76 & Expansion & 41 & Evaluation & 34 & Chemistry & 29 & Purification & 25 \\
\hline Safety & 74 & Relation & 41 & Reduction & 34 & Consultation & 29 & Apartment & 25 \\
\hline Matter & 72 & Whole land & 40 & Asbestos & 34 & Site & 29 & Establishment & 25 \\
\hline Committee & 71 & Incheon & 40 & Dam & 34 & Health & 29 & Habitat & 25 \\
\hline Facility & 69 & Approximately & 40 & River & 33 & Designation & 28 & Industry & 25 \\
\hline Occurrence & 68 & Controversy & 40 & Treatment & 33 & Concern & 28 & Extinction & 25 \\
\hline
\end{tabular}

Table 2. Results of the factor analysis.

\begin{tabular}{cccccccccc}
\hline \multirow{2}{*}{ Component } & \multicolumn{3}{c}{ Initial Eigenvalue } & \multicolumn{2}{c}{ Extraction Sums of Squared Load } & \multicolumn{3}{c}{ Rotation Sums of Squared Load } \\
\cline { 2 - 10 } & Total & $\begin{array}{c}\text { \% of } \\
\text { Variance }\end{array}$ & $\begin{array}{c}\text { Cumulant } \\
\mathbf{( \% )}\end{array}$ & Total & $\begin{array}{c}\text { \% of } \\
\text { Variance }\end{array}$ & $\begin{array}{c}\text { Cumulant } \\
(\%)\end{array}$ & Total & $\begin{array}{c}\text { \% of } \\
\text { Variance }\end{array}$ & $\begin{array}{c}\text { Cumulant } \\
(\%)\end{array}$ \\
\hline 1 & 5.863 & 36.643 & 36.643 & 5.863 & 36.643 & 36.643 & 3.445 & 21.533 & 21.533 \\
2 & 1.417 & 8.856 & 45.500 & 1.417 & 8.856 & 45.500 & 3.007 & 18.796 & 40.328 \\
3 & 1.285 & 8.032 & 53.532 & 1.285 & 8.032 & 53.532 & 2.113 & 13.204 & 53.532 \\
\hline
\end{tabular}

Kaiser-Meyer-Olkin $=0.881$, Bartlett $\mathrm{x}^{2}=683.752, \mathrm{df}=120, p=0.000$.

Mapping the environmental conflicts revealed distinct regional characteristics (Figure 2). Regions sensitive to the characteristic of "atmosphere" (Factor 1) exhibited high factor values across the country, although western municipalities relatively close to China were more sensitive. This trend implies that the problem of fine dust is a general problem in Korea; however, urgent measures are required to respond to the needs of western municipalities in particular. Regarding areas sensitive to the characteristic of "development" (Factor 2), the southern regions from Jeju Island had a high factor value. This indicates severe pressure to develop in the southern region, especially Jeju Island. Furthermore, in areas sensitive to the characteristic of "safety" (Factor 3), densely populated rural metropolitan areas in southern regions such as Ulsan, Daegu, Busan, and Daejeon had a high factor value. Moreover, factors with a variance of less than 0.1 and a positive mean were verified to explore the common keywords between them (Table 4). As a result, keywords including "management", "organization", "progress", "ecology", and "committee" were extracted. This confirmed that measures that manage progress via the work of various groups and committees and supplement ecological aspects were commonly applied to Factor 3. 
Table 3. Main extracted keywords (with a factor value $\geq 2$ ) and distribution of subject areas by factor value.

\begin{tabular}{|c|c|c|c|c|c|}
\hline Factor & Subject Area & Factor Value & Keyword & Load & Major Conflict \\
\hline $\begin{array}{l}1: \\
\text { Sensitivity to "atmosphere" }\end{array}$ & $\begin{array}{c}\text { Seoul } \\
\text { Chungbuk } \\
\text { Gyeonggi } \\
\text { Gwangju } \\
\text { Jeonnam } \\
\text { Chungnam } \\
\text { Gangwon }\end{array}$ & $\begin{array}{l}0.742 \\
0.674 \\
0.673 \\
0.587 \\
0.568 \\
0.567 \\
0.562\end{array}$ & $\begin{array}{c}\text { Citizen } \\
\text { Region } \\
\text { Fine dust } \\
\text { Measure } \\
\text { Resident } \\
\text { Power plant } \\
\text { Park } \\
\text { Project } \\
\text { Occurrence } \\
\text { Policy } \\
\text { Energy } \\
\text { Need } \\
\text { Planning }\end{array}$ & $\begin{array}{l}4.194 \\
3.758 \\
3.614 \\
2.442 \\
2.295 \\
2.230 \\
1.851 \\
1.760 \\
1.591 \\
1.550 \\
1.404 \\
1.237 \\
1.037 \\
\end{array}$ & $\begin{array}{l}\text { The Seoul Federation for Environmental Movement states: "The government's emergency } \\
\text { reduction measures in response to high concentrations of fine dust are not practical in } \\
\text { Seeul, where high concentrations of fine dust occur on a daily basis due to high standards } \\
\text { for issuance. Vehicle regulation and reduced operation are limited to public administrative } \\
\text { agencies, and the application standards and follow-up measures in case of violation are } \\
\text { unclear. Fine dust in subways and stations is also very serious. Practical and effective } \\
\text { measures are required that place citizens' health first. Accordingly, Seoul Federation For } \\
\text { Environmental Movement is conducting an intensive citizen action campaign urging } \\
\text { additional measures against coal-fired electrical power plants and diesel vehicles, which are } \\
\text { the main sources of fine dust."” }\end{array}$ \\
\hline $\begin{array}{c}\text { 2: } \\
\text { Sensitivity to "development" }\end{array}$ & $\begin{array}{c}\text { Jeju } \\
\text { Gyeongbuk } \\
\text { Jeonbuk } \\
\text { Gyeongnam } \\
\text { Incheon }\end{array}$ & $\begin{array}{l}0.723 \\
0.671 \\
0.608 \\
0.571 \\
0.412\end{array}$ & $\begin{array}{c}\text { Project } \\
\text { Development } \\
\text { Law } \\
\text { Facilitation } \\
\text { Region } \\
\text { Planning } \\
\text { Jeju Island } \\
\text { Facility } \\
\text { Park } \\
\text { Investigation } \\
\text { Dam } \\
\text { City } \\
\text { Resident } \\
\text { Incheon } \\
\text { Pollution } \\
\text { Citizen } \\
\text { Safety }\end{array}$ & $\begin{array}{l}6.852 \\
2.881 \\
2.214 \\
2.183 \\
2.112 \\
1.768 \\
1.540 \\
1.470 \\
1.438 \\
1.427 \\
1.089 \\
1.079 \\
1.053 \\
1.027 \\
1.025 \\
4.405 \\
3.001 \\
\end{array}$ & $\begin{array}{l}\text { The Jeju Federation for Environmental Movement stated: "Jeju OO recreational housing } \\
\text { complex development project, which experienced promotion difficulties due to a Supreme } \\
\text { Court decision, continues to be promoted by the greed of Jeju Island and OOO. In } \\
\text { particular, despite the fact that various trial results acknowledge the fault of Jeju and OOO, } \\
\text { the trial that is distressing local residents and landowners is continuing this year with no } \\
\text { projected end. Along with criticism that legal costs are being wasted on the trial, which is } \\
\text { certain to lose and which is not related to securing publicity or promoting the welfare of } \\
\text { residents, there is growing demand to accept the ruling and return land to landowners. } \\
\text { This demonstrates how bad development projects, such as OO recreational housing } \\
\text { complex development project, can have a huge negative impact on the environment, } \\
\text { society, and local economy." }\end{array}$ \\
\hline $\begin{array}{l}\text { 3: } \\
\text { Sensitivity to "safety" }\end{array}$ & $\begin{array}{l}\text { Ulsan } \\
\text { Daegu } \\
\text { Busan } \\
\text { Daejeon }\end{array}$ & $\begin{array}{l}0.821 \\
0.670 \\
0.569 \\
0.486\end{array}$ & $\begin{array}{l}\text { Construction } \\
\text { Unit } \\
\text { Kori } \\
\text { Asbestos } \\
\text { Problem } \\
\text { Damage } \\
\text { Nakdong River } \\
\text { Government } \\
\text { Public opinion } \\
\text { Construction } \\
\text { Nuclear } \\
\text { Law } \\
\text { Project } \\
\text { Project } \\
\text { Demolition } \\
\text { Region }\end{array}$ & $\begin{array}{l}2.707 \\
2.415 \\
2.394 \\
1.921 \\
1.840 \\
1.685 \\
1.555 \\
1.538 \\
1.493 \\
1.411 \\
1.365 \\
1.290 \\
1.275 \\
1.250 \\
1.102 \\
1.065\end{array}$ & $\begin{array}{l}\text { The Ulsan Federation for Environmental Movement stated: "Regarding the process of } \\
\text { public discussion over Shin-Kori unit } 5 \text { and } 6 \text {, in October, the citizen participatory } \\
\text { deliberation process was completed, and the public opinion committee's recommendations } \\
\text { and the government's final decision were made. The public discussion process was } \\
\text { necessary, but insufficient. Each of the following problems had a profound effect on public } \\
\text { discussion: pre-leakage of information packages and information stealing; participation of } \\
\text { representative pro-nuclear personnel in the expert committee for objective verification; and, } \\
\text { as a result, monopolization of the objective verification process, open intervention of } \\
\text { government-funded research institutes, which are subordinate agencies of the state, } \\
\text { inequality of distribution in Ulsan area, which is the affected area, and inequality for future } \\
\text { generations. As Ulsan, which is the affected area, had the smallest citizen participation } \\
\text { group (seven people), the anxiety within the area, which called for a safe society, was not } \\
\text { properly conveyed to the citizen participatory group. Although the results that came out of } \\
\text { the public discussion process are respectable, measures against damage to residents in the } \\
\text { vicinity of the nuclear power plant should be presented, along with a declaration to reduce } \\
\text { the construction of Shin-Kori unit } 5 \text { and } 6 . \text {." }\end{array}$ \\
\hline
\end{tabular}




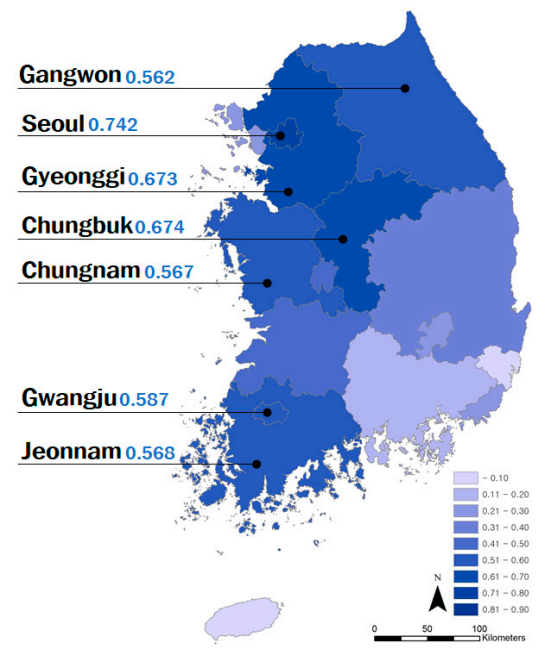

(a)

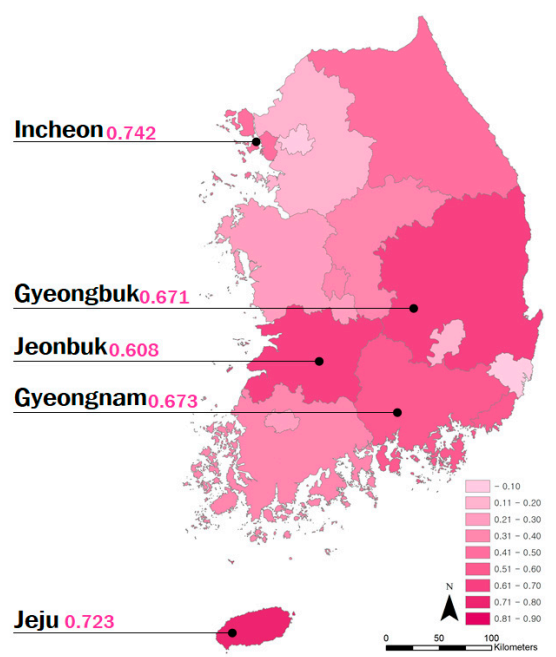

(b)

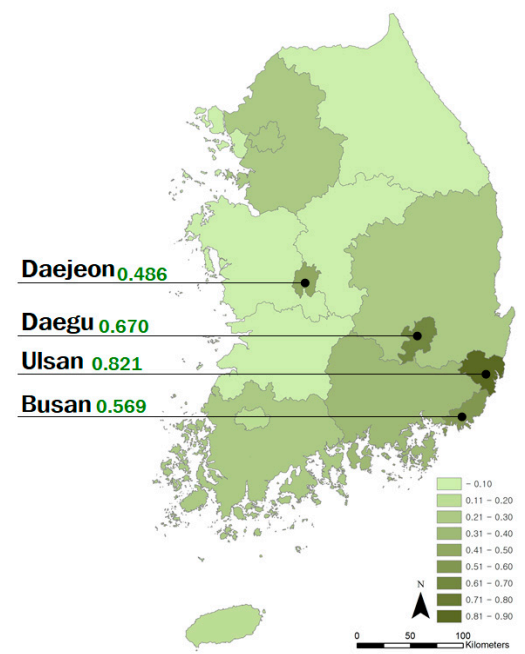

(c)

Figure 2. Maps of environmental conflicts for (a) areas sensitive to the characteristic of "atmosphere", (b) areas sensitive to the characteristic of "development", and (c) areas sensitive to the characteristic of "safety". 
Table 4. Extraction of commonly recognized keywords with a variance $\leq 0.1$.

\begin{tabular}{cccccc}
\hline Keyword & Factor $\mathbf{1}$ & Factor $\mathbf{2}$ & Factor $\mathbf{3}$ & Variance & Mean \\
\hline Management & 0.636 & 0.703 & 0.773 & 0.005 & 0.704 \\
Group & 0.075 & 0.068 & -0.11 & 0.011 & 0.011 \\
Progress & 0.784 & 0.389 & 0.648 & 0.04 & 0.607 \\
Ecology & 0.253 & 0.356 & 0.751 & 0.069 & 0.453 \\
Committee & -0.178 & 0.389 & -0.116 & 0.097 & 0.032 \\
\hline
\end{tabular}

\section{Discussion}

This study used spatial text mining to confirm that degrees of sensitivity exist in environmental conflicts and their regional patterns. According to maps of regional environmental conflicts in South Korea, environmental conflict in this country exhibits distinct characteristics whereby local environments and population densities are intertwined. The results imply that environmental conflict is influenced by these elements because of differences in the opinions of various stakeholders regarding the use of environmental resources; this is reflected by the definition of environmental conflict [1]. Moreover, the results reveal the type of conflict that became a particular issue in each region, identifies areas of concern regarding major issues [5], and provides insights into the implementation of environmental management policies on a spatial level [17]. In South Korea, western municipalities require an environmental policy to manage fine dust, southern urban areas require an environmental policy to manage safety issues, and non-urban areas require an environmental policy to manage issues of development. Therefore, in-depth study into regional environmental conflicts and expert participation in management is required. By strengthening the network among regions experiencing the same types of environmental conflict, an environmental management system can be created that would enable regions to respond jointly to a particular environmental problem and difficulties in conflict management; regions could also share cases in which resolutions were found.

Furthermore, commonly recognized keywords indicate that the entire country should focus on solving environmental conflicts. Keywords including "management", "organization", "progress", and "committee" imply that clear participation techniques, such as forming public opinion committees, should be established as methods of mitigating environmental conflicts [18]. Moreover, the keyword "ecology" indicates the need for practical ways to spread and implement ecological values as alternatives to resolving environmental conflicts.

Mapping environmental conflicts in this way is effective for creating a broad-scale alternative to environmental conflict management, because it can verify the relationship between conflicts that may be perceived as different events in each region, thereby enabling a combined response [1]. Furthermore, this technique can predict the types of environmental change that will have significant effects on local populations, as well as the type of environmental conflict that will occur and in which region, by exploring the forms of conflict between the environment and people. This then allows the preemptive preparation of measures to reduce environmental conflicts during planned projects. As such, environmental conflict maps constitute data that diagnose the current status of environmental conflict while providing alternative methods of solving environmental conflict and aiding preparation for the future.

\section{Conclusions}

This study mapped environmental conflicts in South Korea in order to identify the organic connections between different conflicts instead of treating them as single events, then suggested broad plans for managing such conflicts. First, the major environmental conflicts were verified and their spatial context determined via spatial text mining of key environmental conflicts in South Korea. The results confirmed that environmental conflicts exhibit distinct environmental characteristics and that local environments and population densities are intertwined. 
Korea has had numerous civil complaints related to problems with fine dust pollution and development. Accordingly, the Ministry of Environment has responded by implementing various atmospheric and development regulations. However, these common regulatory policies were implemented nationwide, from urban and industrial areas to rural areas, forests, and islands; thus, questions have been raised about the regional effectiveness and hostility toward these regulations. Further, regarding nuclear safety issues, a public hearing was held only in Ulsan area, and no special alternative was prepared for provincial cities where other nuclear power plant facilities are located. This study is significant because it reveals the major environmental conflict issues in South Korea (fine dust pollution, development, nuclear safety) through environmental conflict mapping, and proposes a tool for creating regionally customized land regulation and management plans for each issue.

Moreover, the proposed spatial text mining technique identifies environmental ecological characteristics such as species type, as well as general human and social characteristics such as population, by analyzing existing environmental spatial data. This technique also identifies distinct characteristics of the area based on the needs of local citizens. Furthermore, combining big data (social networking service data such as Twitter, Facebook, YouTube, and Flickr) $[19,20]$ and regional micro data (in-depth interviews and civil complaints) [21,22] would enable the prioritization of land-use policies specialized for each location. When determining such priorities, spatial text mining could provide important data that represents the needs and opinions of local residents.

Since this study analyzed only the environmental agenda at the local government scale in Korea via spatial text mining, it has a limited ability to map and reveal relationships between the environment and human populations on detailed spatial scales. In addition, like the environment, environmental conflicts can change over time; however, this was beyond the scope of this study. Therefore, future environmental conflict mapping research that employs more diverse data, spatial scales, and time periods will produce richer and more detailed measures for managing environmental conflicts.

Author Contributions: Conceptualization, J.-h.L. and D.-k.K.; methodology, J.-h.L.; software, J.-h.L.; formal analysis, J.-h.L.; investigation, D.-k.K.; resources, D.-k.K.; data curation, D.-k.K.; writing—original draft preparation, J.-h.L. and D.-k.K.; writing-review and editing, J.-h.L.; visualization, J.-h.L.; supervision, D.-k.K.; project administration, D.-k.K.; funding acquisition, D.-k.K. All authors have read and agreed to the published version of the manuscript.

Funding: This research was supported by the grant from basic project 'Social model development of environmental pollution damage for recovery of victims' lives' funded by the Korea Environmental Institute (RE2020-17) and 'Urban-based complex plant demonstration study utilizing underground space' program funded by Ministry of Land, Infrastructure and Transport of Korean government (20UGCP-B157945-01).

Conflicts of Interest: The authors declare no conflict of interest.

\section{References}

1. Scheidel, A.; Del Bene, D.; Liu, J.; Navas, G.; Mingorría, S.; Demaria, F.; Avila, S.; Roy, B.; Ertör, I.; Temper, L.; et al. Environmental conflicts and defenders: A global overview. Glob. Environ. Chang. 2020, 63, 102-104. [CrossRef] [PubMed]

2. Le Billon, P. Wars of Plunder: Conflicts, Profits and the Politics of Resources; Columbia University Press: New York, NY, USA, 2012.

3. Staniscia, B.; Komatsu, G.; Staniscia, A. Nature park establishment and environmental conflicts in coastal areas: The case of the Costa Teatina National Park in central Italy. Ocean Coast. Manag. 2019, 182, 104947. [CrossRef]

4. Hanaček, K.; Rodríguez-Labajos, B. Impacts of land-use and management changes on cultural agroecosystem services and environmental conflicts-A global review. Glob. Environ. Chang. 2018, 50, 41-59. [CrossRef]

5. Carranza, D.M.; Varas-Belemmi, K.; De Veer, D.; Iglesias-Müller, C.; Coral-Santacruz, D.; Méndez, F.A.; Torres-Lagos, E.; Squeo, F.A.; Gaymer, C.F. Socio-environmental conflicts: An underestimated threat to biodiversity conservation in Chile. Environ. Sci. Policy 2020, 110, 46-59. [CrossRef] 
6. Soytong, P.; Perera, R. Use of GIS tools for environmental conflict resolution at Map Ta Phut Industrial Zone in Thailand. Sustainability 2014, 6, 2435-2458. [CrossRef]

7. Kim, I.; Arnhold, S. Mapping environmental land use conflict potentials and ecosystem services in agricultural watersheds. Sci. Total Environ. 2018, 630, 827-838. [CrossRef]

8. Abram, N.K.; Meijaard, E.; Wilson, K.A.; Davis, J.T.; Wells, J.A.; Ancrenaz, M.; Budiharta, S.; Durrant, A.; Fakhruzzi, A.; Runting, R.K.; et al. Oil palm-community conflict mapping in Indonesia: A case for better community liaison in planning for development initiatives. Appl. Geogr. 2017, 78, 33-44. [CrossRef]

9. Brown, G.; Kangas, K.; Juutinen, A.; Tolvanen, A. Identifying environmental and natural resource management conflict potential using participatory mapping. Soc. Nat. Resour. 2017, 30, 1458-1475. [CrossRef]

10. Lee, J.-H.; Park, H.-J.; Kim, I.; Kwon, H.-S. Analysis of cultural ecosystem services using text mining of residents' opinions. Ecol. Indic. 2020, 115, 106368. [CrossRef]

11. Häberle, M.; Werner, M.; Zhu, X.X. Geo-spatial text-mining from Twitter-a feature space analysis with a view toward building classification in urban regions. Eur. J. Remote Sens. 2019, 52, 2-11. [CrossRef]

12. Gulnerman, A.G.; Karaman, H. Spatial reliability assessment of social media mining techniques with regard to disaster domain-based filtering. ISPRS Int. J. Geo-Inf. 2020, 9, 245. [CrossRef]

13. Ghosh, D.; Guha, R. What are we 'tweeting' about obesity? Mapping tweets with topic modeling and Geographic Information System. Cartogr. Geogr. Inf. Sci. 2013, 40, 90-102. [CrossRef] [PubMed]

14. Park, S.B.; Kim, J.; Lee, Y.K.; Ok, C.M. Visualizing theme park visitors' emotions using social media analytics and geospatial analytics. Tour. Manag. 2020, 80, 104-127. [CrossRef]

15. Luhn, H.P. A business intelligence system. IBM J. Res. Dev. 1958, 2, 314-319. [CrossRef]

16. Taminiau, Y.; Ferguson, J.; Moser, C. Instrumental client relationship development among top-ranking service professionals. Serv. Ind. J. 2016, 36, 789-808. [CrossRef]

17. Soytong, P.; Perera, R. Spatial analysis of the environmental conflict between state, society and industry at the Map Ta Phut-Rayong conurbation in Thailand. Environ. Dev. Sustain. 2017, 19, 839-862. [CrossRef]

18. Wittmer, H.; Rauschmayer, F.; Klauer, B. How to select instruments for the resolution of environmental conflicts? Land Use Policy 2006, 23, 1-9. [CrossRef]

19. Kim, Y.; Kim, C.K.; Lee, D.K.; Lee, H.W.; Andrada, R.I.T. Quantifying nature-based tourism in protected areas in developing countries by using social big data. Tour. Manag. 2019, 72, 249-256. [CrossRef]

20. Lee, H.; Seo, B.; Koellner, T.; Lautenbach, S. Mapping cultural ecosystem services 2.0-Potential and shortcomings from unlabeled crowd sourced images. Ecol. Indic. 2019, 96, 505-515. [CrossRef]

21. Lee, C.H. Understanding rural landscape for better resident-led management: Residents' perceptions on rural landscape as everyday landscapes. Land Use Policy 2020, 94, 104565. [CrossRef]

22. Lee, J.H.; Choi, H. An analysis of public complaints to evaluate ecosystem services. Land 2020, 9, 62. [CrossRef]

(C) 2020 by the authors. Licensee MDPI, Basel, Switzerland. This article is an open access article distributed under the terms and conditions of the Creative Commons Attribution (CC BY) license (http://creativecommons.org/licenses/by/4.0/). 